ISSN 0103-8478

\title{
Tepoxalin on renal function and liver enzymes in cats exposed to hypotension with isoflurane
}

\author{
Tepoxalina sobre a função renal e as enzimas \\ hepáticas em gatos submetidos à hipotensão com isofluorano
}

\author{
Gabrielle Coelho Freitas ${ }^{\mathrm{I}}$ Adriano Bonfim Carregaro ${ }^{\mathrm{I}{ }^{*}}$ Shayne Pedrozo Bisetto ${ }^{\mathrm{II}}$ \\ Aline Soares Barbosa ${ }^{\text {II }}$ Paulo Fantinato Neto ${ }^{\text {II }}$ \\ Deise Carla Almeida Leite Dellova ${ }^{\text {II }}$ Carlize Lopes ${ }^{\text {III }}$
}

ABSTRACT

This study aimed to evaluate the possible renal and hepatic toxicity of tepoxalin administered before or after isofluraneinduced hypotension, as well as for five consecutive days. Twelve healthy mixed-breed cats, adult males, weighing $4.0 \pm 0.8 \mathrm{~kg}$ were allocated into two groups. They received $25 \mathrm{mgkg}^{-1}$ of tepoxalin orally, two hours before the anesthetic procedure (PRE) or after the procedure (POST) and daily for five days. Cats were anesthetized with isoflurane and the concentration was increased until mean arterial pressure reached $40-60 \mathrm{mmHg}$ and kept at this level for 60 minutes. During hypotension, the physiological variables were measured at time 0 and every 10 minutes until 60 minutes, and bleeding time was measured at time 0, 30 and 60 minutes. Blood samples were drawn for a hemogram and determination of concentrations of alanine aminotransferase, alkaline phosphatase, urea, creatinine and $\mathrm{Na}^{+}$at baseline, 24 hours, 48 hours and 7 days post-hypotension. Urine was collected at baseline, 24 hours, 48 hours and 7 days post-hypotension for determination of concentrations of creatinine, gamma-glutamyltransferase, urine specific gravity, protein, albumin and $\mathrm{Na}^{+}$. During the anesthetic procedure there were no important variations in physiological variables and bleeding time. There were differences only in fractional excretion of $\mathrm{Na}^{+}$, which was elevated at 7 days of evaluation in PRE and in the urine protein/creatinine ratio in PRE, which was higher than in POST at 24 and 48 hours posthypotension. We conclude that tepoxalin does not cause alterations in hepatic enzymes but can cause discrete renal injury, resulting in proteinuria, in cats subjected to 60min of hypotension.

Key words: non-steroidal anti-inflammatory drug, nephrotoxicity, hepatotoxicity.

\section{RESUMO}

Este estudo teve como objetivo a avaliação da possível toxicidade renal e hepática da tepoxalina administrada antes ou após hipotensão induzida por isofluorano, assim como a sua administração nos cinco dias seguintes à hipotensão. 12 gatos adultos hígidos, machos, sem raça definida e com peso de $4,0 \pm 0,8 \mathrm{~kg}$ foram alocados em dois grupos $(n=6)$. Os animais receberam $25 \mathrm{mgkg}^{-1}$ de tepoxalina pela via oral, duas horas antes do procedimento anestésico (PRE) ou após o procedimento (POST) e diariamente por cinco dias consecutivos. Os gatos foram anestesiados com isofluorano, aumentando-se a sua concentração até que se atingisse uma pressão arterial média entre 40 e $60 \mathrm{mmHg}$, sendo mantida durante 60 minutos. Durante o procedimento de hipotensão, os parâmetros fisiológicos foram mensurados no tempo 0 e a cada dez minutos até o fim do procedimento. O tempo de sangramento da mucosa oral foi avaliado no tempo 0 e aos 30 e 60 minutos de hipotensão. Amostras sanguíneas foram colhidas para a determinação de hemograma, alanina aminotransferase, fosfatase alcalina, ureia, creatinina e sódio no período basal e às 24 horas, 48 horas e sete dias pós-hipotensão. Amostras de urina foram colhidas por meio de cistocentese para a determinação de creatinina, gammaglutamiltransferase, densidade específica, proteínas, albumina e sódio. Durante o período anestésico, não ocorreram alterações referentes aos parâmetros fisiológicos e ao tempo de sangramento. Ocorreram alterações apenas na excreção fracionada de sódio, a qual demonstrou elevação no PRE aos sete dias, e na razão proteína/creatinina na urina, a qual demonstrou elevação do PRE em relação ao POST às 24 e às 48 horas de avaliação. Concluiu-se que a tepoxalina não causou alterações nas enzimas hepáticas, mas pode causar discreta injúria renal, com a presença de proteinúria, em gatos que foram submetidos à hipotensão.

Palavras-chave: anti-inflamatório não esteroidal, nefrotoxicidade, hepatotoxicidade.

\footnotetext{
'Universidade Federal da Fronteira Sul (UFFS), Realeza, PR, Brasil. Pirassununga, SP, Brasil. E-mail: carregaro@usp.br.*Autor para correspondência. SP, Brasil.

"Faculdade de Zootecnia e Engenharia de Alimentos (FZEA), Universidade de São Paulo (USP), Av. Duque de Caxias Norte, 225, 13635-900,

"IIFaculdade de Medicina Veterinária e Zootecnia (FMVZ), Universidade Estadual Paulista Júlio de Mesquita Filho (UNESP), Botucatu, 


\section{INTRODUCTION}

The treatment of pain in cats has been historically neglected despite its known benefits (WRIGHT, 2002; JOUBERT, 2006; LASCELLES et al., 2007). This can be attributed to reduced ability of biotransformation via hepatic glucuronidationin this species, with consequent susceptibility to intoxication by drugs including non-steroidal anti-inflammatory drugs (NSAIDS) (WRIGHT, 2002). Another important point is the difficulty of recognizing and quantifying the intensity of pain in cats (BRONDANI et al., 2011), since these animals do not express evident signs of pain (WRIGHT, 2002).

There is evidence of the analgesic efficacy of NSAIDS in this species, for various surgical procedures (SLINGSBY \& WATERMANPEARSON, 2000; AL-GIZAWIY \& RUDE, 2004; BENITO-DE-LA-VIBORA et al., 2008; MURISON et al., 2010) or in musculoskeletal diseases (GIRAUDEL et al., 2010), resulting in minimal adverse effects.

Tepoxalin is an NSAID with a double inhibitory characteristic, with consequent antiinflammatory action potentiated by inhibiting the COX and 5-LOX pathways (KNIGHT et al., 1996). Tepoxalin has been demonstrated to be a potent dual inhibitor in dogs (ARGENTIERI et al., 1994; KNIGHT et al., 1996; AGNELLO et al., 2005) and did not cause adverse effects during hypotension (LOPES et al., 2013). Tepoxalin is also known to inhibit COX and 5-LOX in cats (GOODMAN et al., 2010), but there are still no studies on its safety and efficacy in this species.

Preventive analgesia in surgical procedures has been shown to be beneficial, and tepoxalin is an advantageous option as part of multimodal analgesia protocols, because of its potent anti-inflammatory action and low incidence of side effects, as reported in dogs. Due to the real possibility of hypotension during anesthetic procedures, the aim of the present study was to evaluate the possible renal and hepatic toxicity of tepoxalin administered before or after isoflurane-induced hypotension, as well as for five consecutive days.

\section{MATERIAL AND METHODS}

Animals and experimental design

Twelve healthy cats were utilized: adult males, of mixed-breed, weighing $4.06 \pm 0.78 \mathrm{~kg}$. Cats were deemed healthy based on physical examination andlaboratory tests: hemogram, serum levels of alanine aminotransferase (ALT), alkaline phosphatase (AP), urea $(\mathrm{U})$ and creatinine $(\mathrm{Cr})$, urinary concentrations of Cr, gamma-glutamyltransferase (GGT), total proteinand albumin, urine specific gravity, fractional excretion of sodium (FENa), and tests for feline immunodeficiency virus (FIV) and of feline leukemia virus (FeLV). The animals were housed in a cattery with solarium and individual cages, for a minimal period of 15 days for acclimation, and received commercial feed and water ad libitum.

Afterwards, the animals were allocated into two groups $(n=6)$, which received tepoxalin ${ }^{a}$ orally, two hours before the anesthetic procedure or after the procedure. Due to the commercial formulation of tepoxalin being available only in tablets and to avoid breaking them up, the dosage was adjusted so that each animal received a dose close to $25 \mathrm{mgkg}^{-1}$. All cats received the same dose of tepoxalin every 24h, for five days after the procedure.

Hypotension procedure and physiological variables Hypotension was induced by fasting the animals for 12 hours, and then anesthetizing them with isoflurane ${ }^{\mathrm{b}}$, in oxygen $(\mathrm{Fi}=0.6)$ and medical compressed air $(\mathrm{Fi}=0.4)$, administered via a Bain nonrebreathing system with a facemask and vaporization necessary for the procedure. Next, the animals were intubated with an endotracheal tube of adequate diameter and maintained undergeneral inhalation anesthesia. Mechanical ventilation was utilized at a pressure of $10 \mathrm{cmH}_{2} \mathrm{O}(\mathrm{I} / \mathrm{E} 1: 2)$, with the respiratory rate adjusted to maintain the end-tidal carbon dioxide partial pressure $\left(\mathrm{ETCO}_{2}\right)$ between 35 and $45 \mathrm{mmHg}$. Physiological solution was administered at $3 \mathrm{mLkg}^{-1} \mathrm{~h}^{-1}$, via a catheter placed in a cephalic vein, using an infusion pump ${ }^{c}$.

Systolic (SAP), mean (MAP) and diastolic (DAP) arterial pressure were measured by means of a sensor positioned in the dorsal pedal artery and connected to a transducer zeroed at the level of the sternum, heart rate (HR) and cardiac rhythm were measured by means of electrodes via derivation II, and hemoglobin oxygen saturation $\left(\mathrm{SaO}_{2}\right)$ were measured using a sensor positioned on the tongue ${ }^{d}$. The temperature of the animals was kept between 37 and $38^{\circ} \mathrm{C}$, by use of a thermal mattress. Patient preparation and stabilization time was standardized to 30 minutes.

After the period of preparation and stabilization, HR, SAP, MAP, DAP, ETCO ${ }_{2}$, end-tidal isoflurane concentration (ETIso), and $\mathrm{SaO}_{2}$ (baseline) were measured. Afterwards, ETIso was elevated by $0.25 \%$ every 3 minutes until MAP reached 40 to 
60mmHg. MAP was maintained within this range for $60 \mathrm{~min}$. In case MAP was below 40mmHg, ETIso was reduced. Afterwards, the variables were measured again (0 minute), and every 10 minutes, for 60 minutes. Bleeding time was also determined before induction of hypotension and at 30 and 60 minutes, by puncture of the inner side of the ear using a lancet after antiseptic skin preparation.

Hepatic and renal evaluation

Blood samples were drawn by jugular venipuncture for determination of ALT, AP and U before the anesthetic procedure (baseline), and at 24 hours and 7 days post-hypotension. $\mathrm{Cr}$ and $\mathrm{Na}^{+}$were also determined at the described times plus at 48 hours post-hypotension. Total leukocytes, erythrocytes, hematocrit $(\mathrm{Ht})$, hemoglobin $(\mathrm{Hb})$, mean corpuscular volume, mean corpuscular hemoglobin and mean corpuscular hemoglobin concentrations were measured at baseline and 48 hours and 7 days post-hypotension.

A volume of $5 \mathrm{~mL}$ of urine was collected by cystocentesis with a $24 \mathrm{G}$ needle, at baseline and at 24 hours, 48 hours and 7 days post-hypotension, for determination of Cr, GGT (DeSCHEPPER et al., 1989), urine specific gravity, protein, albumin and sodium concentrations.

Fractional excretion of $\mathrm{Na}^{+}$(FENa) was calculated using the equation $\mathrm{FENa}=\left(\mathrm{U}_{\mathrm{Na}} \times \mathrm{P}_{\mathrm{Cr}}\right) /$ $\left(\mathrm{P}_{\mathrm{Na}} \times \mathrm{U}_{\mathrm{Cr}}\right) \times 100$, where $\mathrm{U}_{\mathrm{Na}}$ is the concentration of $\mathrm{Na}^{+}$in the urine, $\mathrm{P}_{\mathrm{Cr}}$ is the plasma concentration of creatinine, $\mathrm{P}_{\mathrm{Na}}$ is the plasma concentration of $\mathrm{Na}^{+}$ and $U_{\mathrm{Cr}}$ is the urinary concentration of creatinine (WALDROP, 2008). Total protein and albumin in the urine were measured using commercial kits and spectrophotometry ${ }^{\text {e }}$. Urinary protein was determined by the pyrogallol red method ${ }^{\mathrm{f}}$ at $600 \mathrm{~nm}$ and urinary albumin by the bromocresol green method ${ }^{\mathrm{g}}$ at $625 \mathrm{~nm}$. The results obtained were corrected using the volume of urine produced, considering the ratios between urine protein and creatinine, and between urine albumin and creatinine.

Finally, the animals were observed for possible clinical abnormalities such as anorexia, vomiting, diarrhea or constipation, emesis and gastrointestinal bleeding during the 7 days of evaluation.

\section{Statistical analysis}

The data were tested for normal distribution by the Kolmogorov-Smirnov ${ }^{\mathrm{h}}$ test and statistical analysis was carried out by repeated measures ANOVA followed by Dunnett's test for comparisons within each group, in relation to time 0min (anesthetic) or baseline (biochemical) for all variables, except clinical abnormalities, bleeding time, urine specific gravity, GGT, urine GGTcreatinine ratio, urine protein/Cr ratio and urine albumin-Cr ratio. Comparisons between the groups at each time were carried out using the unpaired t-test. Non-parametric data (bleeding time, urine specific gravity, GGT, urine GGT-creatinine ratio, urine protein-Cr ratio and urine albumin-Cr ratio) were evaluated by Friedman's test followed by Dunn's test for comparisons within each group, in relation to baseline, and by Mann-Whitney test for comparisons between the groups at each time. Parametric variables were expressed as mean \pm standard deviation and non-parametric variables were expressed as median \pm interquartile range. The differences were considered significant when $\mathrm{P}<0.05$.

\section{RESULTS}

The doses of tepoxalin were similar between the groups: $25.1 \mathrm{mgkg}^{-1}$ for the PRE group $(4.0 \pm 0.78 \mathrm{~kg})$ and $24.2 \mathrm{mgkg}^{-1}$ for the POST group $(4.1 \pm 0.31 \mathrm{~kg})$.

The anesthetic procedure was effective in maintaining the target blood pressure. The variables evaluated remained stable and within the physiological range, with the exception of arterial pressures, obviously due to the induced hypotension with isoflurane (Table 1). No alterations were observed in bleeding time (Table 1).

There were no differences in ALT, AP, $\mathrm{U}, \mathrm{Cr}, \mathrm{Ht}$ and $\mathrm{Hb}$ in comparisons within or between groups at each time (Table 2). In urinary analysis (Table 2), there were no observed alterations in urine especific gravity, Cr, GGT and GGT-creatinine ratio. FENa was elevated only at 7 days of evaluation in PRE. The urine protein-creatinine ratio in PRE was higher than in POST at 24 and 48 hours posthypotension, while no alterations were observed for the urine albumin-creatinine ratio (Table 2) or clinical abnormalities, during the study.

\section{DISCUSSION}

We studied the administration of tepoxalin in cats because of the scarcity of information on its clinical effects in this species and the easiness of administration since the commercially available tablets dissolve rapidly in contact with the moist oral cavity. The use before and after the anesthetic procedure allowed the comparison of administrations at different time points, because as noted, the use of NSAIDS is routine in analgesic treatment and since 
Table 1 -Heart rate (HR), systolic (SAP), mean (MAP) and diastolic arterial preasure (DAP), hemoglobin oxygen saturation (SaO ${ }_{2}$ ), end-tidal isoflurane concentration (ETIso) and bleeding time obtained from twelve cats subjected to hypotension with isoflurane and pretreated (PRE) or treated after hypotension (POST) with $25 \mathrm{mgkg}^{-1}$ of tepoxalin during 5 days. Values of HR, SAP, MAP, DAP, $\mathrm{SaO}_{2}$ and ETIso expressed as mean $\pm \mathrm{SD}$. Bleeding time expressed as median \pm interquartile range. $\mathrm{P}<0.05$.

\begin{tabular}{|c|c|c|c|c|c|c|c|c|}
\hline \multirow{2}{*}{ Group } & \multicolumn{8}{|c|}{ - } \\
\hline & Baseline & 0 & 10 & 20 & 30 & 40 & 50 & 60 \\
\hline \multicolumn{9}{|c|}{ HR (bpm) } \\
\hline PRE & $148 \pm 25$ & $146 \pm 23$ & $137 \pm 12$ & $136 \pm 14$ & $136 \pm 14$ & $142 \pm 10$ & $140 \pm 9$ & $139 \pm 8$ \\
\hline POST & $148 \pm 27$ & $145 \pm 22$ & $144 \pm 26$ & $134 \pm 18$ & $132 \pm 18$ & $128 \pm 16$ & $126 \pm 16$ & $132 \pm 7$ \\
\hline \multicolumn{9}{|c|}{$\mathrm{SAP}(\mathrm{mmHg})$} \\
\hline PRE & $111 \pm 13$ & $77 \pm 12$ & $75 \pm 8$ & $76 \pm 6$ & $74 \pm 13$ & $76 \pm 7$ & $75 \pm 6$ & $76 \pm 9$ \\
\hline POST & $99 \pm 18$ & $76 \pm 8$ & $79 \pm 9$ & $75 \pm 5$ & $77 \pm 8$ & $78 \pm 3$ & $76 \pm 11$ & $88 \pm 15$ \\
\hline \multicolumn{9}{|c|}{ MAP (mmHg) } \\
\hline PRE & $72 \pm 18$ & $50 \pm 8$ & $46 \pm 10$ & $44 \pm 6$ & $48 \pm 9$ & $44 \pm 8$ & $47 \pm 8$ & $47 \pm 8$ \\
\hline POST & $71 \pm 13$ & $45 \pm 5$ & $50 \pm 7$ & $46 \pm 5$ & $49 \pm 3$ & $47 \pm 2$ & $48 \pm 8$ & $57 \pm 12$ \\
\hline \multicolumn{9}{|c|}{ DAP (mmHg) } \\
\hline PRE & $52 \pm 12$ & $25 \pm 10$ & $25 \pm 8$ & $28 \pm 7$ & $27 \pm 12$ & $26 \pm 10$ & $28 \pm 8$ & $32 \pm 10$ \\
\hline POST & $44 \pm 17$ & $26 \pm 3$ & $29 \pm 8$ & $25 \pm 3$ & $31 \pm 7$ & $29 \pm 2$ & $30 \pm 13$ & $36 \pm 10$ \\
\hline \multicolumn{9}{|c|}{$\mathrm{SaO}_{2}(\%)$} \\
\hline PRE & $98 \pm 1$ & $98 \pm 2$ & $97 \pm 2$ & $98 \pm 1$ & $99 \pm 1$ & $99 \pm 1$ & $97 \pm 1$ & $98 \pm 2$ \\
\hline POST & $98 \pm 1$ & $98 \pm 1$ & $98 \pm 1$ & $98 \pm 1$ & $99 \pm 1$ & $98 \pm 1$ & $98 \pm 2$ & $97 \pm 2$ \\
\hline \multicolumn{9}{|c|}{ ETIso (V\%) } \\
\hline PRE & $2.0 \pm 0.4$ & $2.5 \pm 0.6$ & $2.4 \pm 0.6$ & $2.3 \pm 0.5$ & $2.3 \pm 0.6$ & $2.4 \pm 0.5$ & $2.4 \pm 0.6$ & $2.2 \pm 0.8$ \\
\hline POST & $2.2 \pm 0.7$ & $2.1 \pm 0.5$ & $2.3 \pm 0.5$ & $2.3 \pm 0.5$ & $2.3 \pm 0.5$ & $2.2 \pm 0.4$ & $2.1 \pm 0.3$ & $2.1 \pm 0.3$ \\
\hline \multicolumn{9}{|c|}{ Bleeding time (seconds) } \\
\hline PRE & $90[45 ; 150]$ & NA & NA & NA & $75[60 ; 180]$ & NA & NA & $75[60 ; 120]$ \\
\hline PST & $120[30 ; 120]$ & NA & NA & NA & $75[30 ; 150]$ & NA & NA & $75[30 ; 120]$ \\
\hline
\end{tabular}

$\mathrm{NA}=$ not assessed

hypotension is very common during anesthesia (PASCOE et al., 2006). Thus, it was possible to see if tepoxalin favored a possible worsening of renal ischemia, common in hypotension (POWER et al., 1992; PERKOWSKI \& WETMORE, 2006).

Other studies have demonstrated that tepoxalin has an inhibitory action on COX-1 and 5-LOX in cats (GOODMAN et al., 2010), and contrary to findings in dogs (KNIGHT et al., 1996), its administration in cats does not cause inhibition of COX-2 (GOODMAN et al., 2010). One of the advantages associated with the use of tepoxalin in relation to NSAIDS, with action only on the COX pathway, is the reduced levels of leukotriene $\mathrm{B}_{4}$, which is involved in the recruitment, activation and prolonged action of neutrophils and other inflammatory cells, resulting in injury to the gastrointestinal mucosa (RAINSFORD, 1993; BERTOLINI et al., 2001).

Gastrointestinal alterations are the main adverse effects related to the administration of NSAIDS in dogs (LUNA et al., 2007). In the present study, no clinical abnormalities indicative of gastrointestinal toxicity, such as anorexia, emesis and gastrointestinal bleeding, were found during the period of tepoxalin administration. However, laboratory tests and imaging would provide more accurate information in this respect.

In the present study, bleeding time evaluated the possible interference of tepoxalin with platelet function during the anesthetic period, since one of the posible adverse effects occuring after the administration of NSAIDS is reduced platelet function (PERKOWSKI \& WETMORE, 2006), because these drugs can impair the production of thromboxane $A_{2}$, through the inhibition of COX (BOSTRÖM et al., 2006). However, there were no changes observed in the groups of cats treated with this drug during induced hypotension. This variable was also unchanged in dogs given preoperative tepoxalin (KAY-MUGFORD et al., 2004).

In vitro aggregation tests may be overly sensitive when used to predict drug interference with in vivo coagulation and hemostasis (LEMKE 
Table 2 - Serum levels of alanine aminotransferase (ALT), alkaline phosphatase (AP), urea (U), creatinine (Cr), hematocrit (Ht) and hemoglobin ( $\mathrm{Hb}$ ) and Urine specific gravity, urinary concentrations of creatinine (UCr) and gamma-glutamyltransferase (GGT), urinary GGT-creatinine ratio, fractional excretion of sodium (FENa), urinary protein-creatinine ratio and urinary albumincreatinine ratio obtained from twelve cats subjected to hypotension with isoflurane and pretreated (PRE) or treated after hypotension (POST) with 25 $\mathrm{mgkg}^{-1}$ of tepoxalin during 5 days. Values of ALT, AP, U, Cr, Ht, Hb, UCr and FENa expressed as mean \pm SD. Values of urine specific gravity, GGT, urinary GGT-Cr ratio, urinary protein-creatinine ratio and urinary albuminecreatinine ratio expressed as median \pm interquartile range. $\mathrm{P}<0.05$.

\begin{tabular}{|c|c|c|c|c|}
\hline \multirow{2}{*}{ Group } & \multirow[b]{2}{*}{ Baseline } & \multirow[b]{2}{*}{24 hours } & \multirow[b]{2}{*}{48 hours } & \multirow[b]{2}{*}{7 days } \\
\hline & & & & \\
\hline \multicolumn{5}{|c|}{$\operatorname{ALT}\left(\mathrm{IUL}^{-1}\right)$} \\
\hline PRE & $44 \pm 11$ & $46 \pm 13$ & NA & $45 \pm 11$ \\
\hline POST & $68 \pm 25$ & $78 \pm 21$ & NA & $54 \pm 16$ \\
\hline \multicolumn{5}{|c|}{$\mathrm{AP}\left(\mathrm{IUL}^{-1}\right)$} \\
\hline PRE & $56 \pm 21$ & $56 \pm 21$ & NA & $53 \pm 29$ \\
\hline POST & $38 \pm 13$ & $49 \pm 25$ & NA & $35 \pm 8$ \\
\hline \multicolumn{5}{|c|}{$\mathrm{U}\left(\mathrm{mg} \mathrm{dL}^{-1}\right)$} \\
\hline PRE & $58 \pm 14$ & $58 \pm 17$ & NA & $60 \pm 10$ \\
\hline POST & $53 \pm 9$ & $49 \pm 14$ & NA & $59 \pm 5$ \\
\hline \multicolumn{5}{|c|}{$\mathrm{Cr}\left(\mathrm{mgdL}^{-1}\right)$} \\
\hline PRE & $1.22 \pm 0.12$ & $1.10 \pm 0.09$ & $1.08 \pm 0.12$ & $1.20 \pm 0.17$ \\
\hline POST & $1.32 \pm 0.18$ & $1.20 \pm 0.13$ & $1.13 \pm 0.18$ & $1.17 \pm 0.10$ \\
\hline \multicolumn{5}{|l|}{$\mathrm{Ht}(\%)$} \\
\hline PRE & $42.3 \pm 4.5$ & NA & $41.2 \pm 8.3$ & $42.9 \pm 9.4$ \\
\hline POST & $43.9 \pm 2.9$ & NA & $44.6 \pm 7.8$ & $43.3 \pm 7.3$ \\
\hline \multicolumn{5}{|c|}{$\mathrm{Hb}\left(\mathrm{gdL}^{-1}\right)$} \\
\hline PRE & $13.7 \pm 1.6$ & NA & $12.9 \pm 2.4$ & $13.6 \pm 2.9$ \\
\hline POST & $14.2 \pm 1.1$ & NA & $14.3 \pm 2.65$ & $13.7 \pm 2.4$ \\
\hline \multicolumn{5}{|c|}{ Urinespecific gravity } \\
\hline PRE & $1.071 \pm 0.017$ & $1.066 \pm 0.017$ & $1.065 \pm 0.008$ & $1.072 \pm 0.011$ \\
\hline POST & $1.060 \pm 0.013$ & $1.075 \pm 0.006$ & $1.066 \pm 0.008$ & $1.059 \pm 0.010$ \\
\hline \multicolumn{5}{|c|}{$\mathrm{UCr}\left(\mathrm{IUL}^{-1}\right)$} \\
\hline PRE & $276 \pm 56$ & $233 \pm 32$ & $241 \pm 26$ & $264 \pm 67$ \\
\hline POST & $297 \pm 94$ & $274 \pm 29$ & $293 \pm 80$ & $221 \pm 63$ \\
\hline \multicolumn{5}{|c|}{ Urinary GGT (IUL $\left.{ }^{-1}\right)$} \\
\hline PRE & $22 \pm 7.0$ & $20 \pm 8.0$ & $18 \pm 8.0$ & $16 \pm 1.0$ \\
\hline POST & $25 \pm 6.0$ & $15 \pm 3.0$ & $28 \pm 15$ & $16 \pm 14$ \\
\hline \multicolumn{5}{|c|}{ Urinary GGT-Cr rate } \\
\hline PRE & $0.080 \pm 0.02$ & $0.093 \pm 0.05$ & $0.075 \pm 0.03$ & $0.064 \pm 0.02$ \\
\hline POST & $0.098 \pm 0.05$ & $0.055 \pm 0.01$ & $0.094 \pm 0.43$ & $0.097 \pm 0.02$ \\
\hline \multicolumn{5}{|c|}{ FENa (\%) } \\
\hline PRE & $0.55 \pm 0.13$ & $0.66 \pm 0.06$ & $0.85 \pm 0.20$ & $0.94 \pm 0.45^{*}$ \\
\hline POST & $0.60 \pm 0.15$ & $0.65 \pm 0.15$ & $0.52 \pm 0.39$ & $0.79 \pm 0.24$ \\
\hline \multicolumn{5}{|c|}{ Urinaryprotein-Cr ratio } \\
\hline PRE & $0.14[0 ; 2.39]$ & $1.79[0 ; 2.02]^{\mathrm{A}}$ & $1.92[0 ; 2.23]^{\mathrm{A}}$ & $1.61[0 ; 1.91]$ \\
\hline POST & $0.24[0 ; 0.59]$ & $0.30[0 ; 0.73]^{\mathrm{B}}$ & $1.15[0 ; 3.07]^{\mathrm{B}}$ & $2.00[0 ; 5.1]$ \\
\hline \multicolumn{5}{|c|}{ Urinaryalbumin-Cr ratio } \\
\hline PRE & $0[0 ; 0.03]$ & $0[0 ; 0]$ & $0[0 ; 0.1]$ & $0[0 ; 0]$ \\
\hline POST & $0[0 ; 0]$ & $0[0 ; 0]$ & $0.063[0 ; 0.28]$ & $0.061[0 ; 3.58]$ \\
\hline
\end{tabular}

NA $=$ not assessed.

* Differed from baseline.

Identical superscript letters indicate values that do not differ significantly. 
et al., 2002). Bleeding time is the most common in vivo method used to investigate platelet function abnormalities (BRONDANI et al., 2009). Bleeding time was measured at the external surface of the ear, unlike previous studies in cats (CARROLL et al., 2005; BRONDANI et al., 2009) and the results were comparable to tests performed at the oral mucosa in cats (CARROLL et al., 2005). This test has been criticized when used as a screening test to predict surgical bleeding because of poor predictive performance (LIND, 1991). However, when serial tests are performed on the same patient, as in the present study, information can be gained about the effects of a treatment on in vivo platelet function (KAY-MUGFORD et al., 2004).

Serum creatinine and urea levels remained in the physiological range and showed no statistical differences between the groups. These are the routine tests used to investigate kidney function in cats treated with NSAIDs (SLINGSBY \& WATERMAN-PEARSON, 2002; CARROLL et al., 2005; TOBIAS et al., 2006). However, it should be pointed out that these variables do not change until more than $66 \%$ of nephrons are non-functional (FINCO, 1995; DiBARTOLA, 2010). Thus, their interpretation is limited as a renal indicator. In this case, the evaluation of urinary enzymes is more reliable, which can be used to assess the degree of renal injury through the increase in their excretion, which is normally correlated with the severity of renal damage (CLEMO, 1998).

In the present study, we measured urinary GGT, a glycoprotein found in the microvilli of the proximal tubule, where increased levels give an early indication of injury to the renal tubules, since elevations of this enzyme are sometimes seen without changes in urea and creatinine concentrations (GRECCO et al., 1985; RIVERS et al., 1996). The reported reference values for urinary GGT activity in cats is $19.4 \pm 10.3$ IUL $^{-1}$ (MATSUOKA, 1995), and GGT levels of the cats studied stayed within this range, corroborating the findings in dogs subjected to hypotension, in which the administration of tepoxalin also did not cause alterations in urinary GGT excretion (LOPES et al., 2013).

Comparing the dose of tepoxalin indicated for dogs, which is $20 \mathrm{mgkg}^{-1}$ on the first day and $10 \mathrm{mgkg}^{-1}$ on the following days (KAY-MUGFORD et al., 2004; AGNELLO et al., 2005), it should be noted that higher doses of tepoxalin were used in cats in the present study. Despite the apparent overdose, it should be pointed out that urinary GGT stayed within the physiological range, even after its administration on consecutive days, indicating the lack of injury to renal tubules in the cats in the present study.

Another indicator of early renal damage employed in this study was FeNa, in which again the values observed were within the normal range, that is, below 1\% (DiBARTOLA, 2010; LEFEBVRE et al., 2008). The presence of electrolytes in the urine occurs as a result of processes of tubular reabsorption and secretion, and increase in FENa is an indicator of acute tubular dysfunction (LOBETTI \& LAMBRECHTS, 2000; LEFEBVRE et al., 2008).

Damage to proximal tubules causes loss of microvillosities with consequent decrease in reabsorption and increase in protein excretion (RIVERS et al., 1996), which is of diagnostic or prognostic value in the initial detection and confirmation of renal disease, and can be of considerable importance in the evaluation of therapeutic efficacy and of renal disease progression (ROSSI et al., 2012). In healthy cats, urine proteincreatinine ratio is equal to or less than 0.2 . A ratio between 0.2 and 0.4 is considered the limit; a ratio above 0.4 is indicative of chronic tubulointerstitial or glomerular renal disease; and a ratio above 2.0 is suggestive of glomerular disease (SYME et al., 2006; GRAUER, 2007).

The data refering to proteinuria and albuminuria in the present study suggest the occurrence of discrete renal injury, with urine proteincreatinine ratio above 0.4 in both groups, which could have been caused by hypotension as well as the administration of tepoxalin. Moreover, the increase in proteinuria occurred at the first moment in PRE (24h), suggesting that tepoxalin administered before the anesthetic procedure may have exacerbated the renal injury. In conscious healthy cats, short-term meloxicam administration did not alter proteinuria and glomerular filtration rate (GOODMAN et al., 2009). In cats with reduced renal mass, neither meloxicam nor acetylsalicylic acid caused significantly elevated proteinuria. This study assumes that glomerular filtration rate of euvolemic cats with normal or reduced renal function is not dependent on cyclooxygenase function (SURDYK et al., 2013). A long-term maintenance dose of meloxicam $\left(0.02 \mathrm{mgkg}^{-1}\right)$ can be safely administered in aged cats, even if they have chronic renal disease (GOWAN et al., 2011).

When proteinuria is detected, it is important to localize the source; unfortunately, sediment urinalysis was not done in this study. The cut off point for the urine protein-creatinine ratio does not detect patients with low-level albuminuria, and thus, the determination of the urine albumin- 
creatinine ratio is important to avoid false-negative results of albuminuria (LYON et al., 2010).

In the present study, no hepatic alterations were observed, since there were no changes in the ALT and AP enzyme levels, even after the administration of tepoxalin for consecutive days. ALT and AP were within the physiological range for the species, and there was no difference between the groups. Hepatotoxicity due to the use of NSAIDS can occur due to the release of metabolites conjugated with glucuronic acid, which can cause a hepatic immunological response (BAILEY \& DICKINSON, 2003). Furthermore, reduced hepatic glucuronidation of NSAIDS in cats can minimize this mechanism of metabolite formation (LASCELLES et al., 2007).

\section{CONCLUSION}

On the basis of our results, we conclude that tepoxalin administered prior to or after anesthesiainduced hypotension, as well as given daily for five days following anesthesia, did not cause alterations in hepatic enzymes, serum concentrations of urea and creatinine, fractional sodium excretion and urinary GGT in healthy cats. However, there were indications of discrete renal injury, resulting in proteinuria, in animals medicated with tepoxalin.

\section{ACKNOWLEDGEMENTS}

This study was performed with financial support provided by the Fundação de Amparo à Pesquisa do Estado de São Paulo (FAPESP) grant number 2010/08698-9.

\section{COMMITTEE ON ETHICS AND BIOSAFETY}

The project was approved by the Committee on Ethics and Animal Well-being of the Universidade Federal de Santa Maria, under protocol No. 090/2009.

\section{SOURCES AND MANUFACTERS}

a - Zubrin ${ }^{\circledR}$ - Intervet Schering-Plough Animal Health, Cruzeiro, SP, Brazil.

b - Forane ${ }^{\circledR}$ - Abbott Laboratórios do Brasil LTDA, São Paulo, SP, Brazil.

C - Digipump SR8X ${ }^{\circledR}$ - Digicare Biomedical Technology, Boynton Beach, FL, USA.

d - LifeWindow ${ }^{\mathrm{TM}}$ 6000V ${ }^{\circledR}$ - Digicare Biomedical Technology, Boynton Beach, FL, USA.

e - LabsystemsMultiskan MS ${ }^{\circledR}$ - Labsystems, Helsinki, Filand. f - Sensiprot ${ }^{\circledR}$ - Labtest Diagnóstica SA, Lagoa Santa, MG, Brazil. g - Albumina colorimétrico ${ }^{\circledR}$ - LaborlabProd. Lab. Ltda, Guarulhos, SP, Brazil.

h - GraphPad Prism 5.0 GraphPad Prism ${ }^{\circledR}$ - GraphPad Software Inc, San Diego, CA, USA.

\section{REFERENCES}

AGNELLO, K.A. et al. In vivo effects of tepoxalin, an inhibitor of cyclooxygenase and lipoxygenase, on prostanoid and leukotriene production in dogs with chronic osteoarthritis. Am J Vet Res, v.66, n.6, p.966-972, 2005. Available from: <http://avmajournals.avma. org/doi/pdf/10.2460/ajvr.2005.66.966>. Accessed: jan 14, 2014. doi: 10.2460/ajvr.2005.66.966.

AL-GIZAWIY, M.M.; RUDE, E. Comparison of preoperative carprofen and postoperative butorphanol as postsurgical analgesics in cats undergoing ovariohysterectomy. Vet Anaesth Analg, v.31, n.3, p.164-174, 2004. Available from: < http://onlinelibrary.wiley. com/doi/10.1111/j.1467-2987.2004.00180.x/full >. Accessed: jan 14, 2014. doi: 10.1111/j.1467-2987.2004.00180.x.

ARGENTIERI, D.C. et al. Tepoxalin: a dual cyclooxygenase/5lipoxygenase inhibitor of arachidonic acid metabolism and potent anti-inflammatory activity and a favorable gastrointestinal profile. J Pharmacol Exp Ther, v.271, n.3, p.1399-1408, Dec. 1994. Available from: <http://jpet.aspetjournals.org/content/271/3/1399. long>. Accessed: jan 14, 2014.

BAILEY, M.J.; DICKINSON, R.G. Acyl glucuronidereactity in perspective: biological consequences. Chem Biol Interact, v.145, n.2, p.117-137, 2003. Available from: <http://www. sciencedirect.com/science/article/pii/S0009279703000206>. Accessed: jan 14, 2014.

BENITO-DE-LA-VIBORA, J. et al. Efficacy of tolfenamic acid and meloxicam in the control of post-operative pain following ovariohysterectomy in the cat. Vet Anaesth Analg, v.35, n.6, p.501-510, 2008. Available from: <http://onlinelibrary.wiley.com/ doi/10.1111/j.1467-2987.2004.00175.x/full>. Accessed: jan 14, 2014. doi: 10.1111/j.1467-2995.2008.00407.x.

BERTOLINI, A. et al. Dual acting anti-inflammatory drugs: a reappraisal. Pharmacol Res, v.44, n.6, p.437-450, 2001.

BOSTRÖM, I.M et al. Effects of meloxicam on renal function in dogs with hypotension during anaesthesia. Vet Anaesth Analg, v.33, n.1, p.62-69, 2006. Available from: <http://onlinelibrary. wiley.com/doi/10.1111/j.1467-2995.2005.00208.x/full>. Accessed: jan 14, 2014. doi: 10.1111/j.1467-2995.2005.00208.x.

BRONDANI, J.T. et al. Perioperative administration of vedaprofen, tramadol or their combination does not interfere with platelet aggregation, bleeding time and biochemical variables in cats. J Feline Med Surg, v.11, n.6, p.503-509, 2009. Available from: <http://jfm.sagepub.com/content/11/6/503.long>. Accessed: jan 14, 2014. doi: 10.1016/j.jfms.2008.12.003.

BRONDANI, J.T. et al. Refinement and initial validation of a multidimensional composite scale for use in assessing acute postoperative pain in cats. Available from: <http://avmajournals. avma.org/doi/full/10.2460/javma.243.6.844>. Accessed: jan 14, 2014. Am J Vet Res, v.72, n.2, p.174-183, 2011. doi: 10.2460/ ajvr.72.2.174

CARROLL, G.L. et al. Analgesic efficacy of preoperative administration of meloxicam or butorphanol in onychectomized cats. J Am Vet Med Assoc, v.226, n.6, p.913-919, 2005. doi: 10.2460/javma.2005.226.913.

CLEMO, F.A. Urinary enzyme evaluation of nephrotoxicity in the dog. Toxicol Pathol, v.26, n.1, p.29-32, 1998.

Ciência Rural, v.44, n.6, jun, 2014. 
DeSCHEPPER, J. et al. Urinary gamma-glutamiltransferase and degree of renal dysfunction in 75 bitches with pyometra. Res Vet Sci, v.46, n.3, p.396-400, 1989.

DiBARTOLA, S.P. Clinical approach and laboratory evaluation of renal disease. In: ETTINGER, S.J.; FELDMAN, E.C. (Eds). Textbook of veterinary internal medicine. 7.ed. Philadelphia: Saunders, 2010. Cap.308, p.1955-1969.

FINCO, D.R. Relationship between plasma creatinine concentration and glomerular filtration rate in dogs. J Vet Pharmacol Ther, v.18, n.6, p.418-421, 1995.

GIRAUDEL, J.M. et al. Evaluation of orally administered robenacoxib versus ketoprofen for treatment of acute pain and inflammation associated with musculoskeletal disorders in cats. Am J Vet Res, v.71, n.7, p.710-719, 2010. Available from: <http:// avmajournals.avma.org/doi/pdf/10.2460/ajvr.2005.66.700>. Accessed: jan 14, 2014. doi: 10.2460/ajvr.71.7.710.

GOODMAN, L.A. et al. Effects of meloxicam on plasma iohexol clearance as a marker of glomerular filtration rate in conscious healthy cats. Am J Vet Res, v.70, n.7, p.826-830, 2009. Available from: <http://avmajournals.avma.org/doi/pdf/10.2460/ ajvr.70.7.826>. Accessed: jan 14, 2014. doi: 10.2460/ajvr.70.7.826.

GOODMAN, L.A. et al. Effects of firocoxib, meloxicam, and tepoxalin administration on eicosanoid production in target tissues of healthy cats. Am J Vet Res, v.71, n.9, p.1067-1073, 2010. Available from: <http://avmajournals.avma.org/doi/pdf/10.2460/ ajvr.71.9.1067>. Accessed: jan 14, 2014. doi: 10.2460/ ajvr.71.9.1067.

GOWAN, R.A. et al. Retrospective case-control study of the effects of long-term dosing with meloxicam on renal function in aged cats with degenerative joint disease. J Fel Med Surg, v.13, n.10, p.752-761, 2011. Available from: <http://jfm.sagepub.com/ content/13/10/752.long >. Accessed: jan 14, 2014. doi: 10.1016/j. jfms.2011.06.008.

GRAUER, G.F. Measurement, Interpretation, and Implications of Proteinuria and Albuminuria. Vet Clin North Am Small Anim Pract, v.37, n.2, p.283-295, 2007.

GRECO, D.S. et al. Urinary gamma-glutamyltranspeptidase activity in dogs with gentamicin-induced nephrotoxicity. Am J Vet Res, v.46, n.11, p.2332-2335, 1985.

JOUBERT, K.E. Anaesthesia and analgesia for dogs and cats in South Africa undergoing sterilisation and with osteoarthritis - An update from 2000. J S Afr Vet Assoc, v.77, n.4, p.224-228, 2006.

KAY-MUGFORD, P.A. et al. Effect of preoperative administration of tepoxalin on hemostasis and hepatic and renal function in dogs. Vet Ther, v.5, n.2, p.120-127, 2004.

KNIGHT, E.V. et al. Preclinical toxicity evaluation of tepoxalin, a dual inhibitor of cyclooxygenase and 5-lipoxygenase, in SpragueDawley rats and Beagle dogs. Fundam Appl Toxicol, v.33, n.1, p.38-48, 1996.

LASCELLES, B.D. et al. Nonsteroidal anti-inflammatory drugs in cats: a review. Vet Anaesth Analg, v.34, n.4, p.228-250, 2007. Available from: <http://onlinelibrary.wiley.com/doi/10.1111/ j.1467-2995.2006.00322.x/full>. Accessed: jan 14, 2014. doi: 10.1111/j.1467-2995.2006.00322.x.
LEFEBVRE, H.P. et al. Fractional excretion tests: a critical review of methods and applications in domestic animals. Vet Clin Pathol, v.31, n.1, p.4-20, 2008. Available from: <http://onlinelibrary.wiley. com/doi/10.1111/j.1939-165X.2008.00010.x/full>. Accessed: jan 14, 2014. doi: 10.1111/j.1939-165X.2008.00010.x.

LEMKE, K.A. et al. Effects of preoperative administration of ketoprofen on whole blood platelet aggregation, buccal mucosal bleeding time, and hematologic indicies in dogs undergoing elective ovariohysterectomy. J Am Vet Med Assoc, v.220, n.12, p.1818-1822, 2002.

LIND, S.E. The bleeding time does not predict surgical bleeding. Blood, v.77, p.2547-2552, 1991.

LOBETTI, R.; LAMBRECHTS, N. Effects of general anesthesia and surgery on renal function in healthy dogs. Am J Vet Res, v.61, n.2, p.121-124, 2000. Available from: <http://avmajournals.avma. org/doi/pdf/10.2460/ajvr.2000.61.121>. Accessed: jan 14, 2014. doi: 10.2460/ajvr.2000.61.121.

LOPES, C. et al. Safety of tepoxalin on renal and hepatic functions in dogs exposed to hypotension with isoflurane. Vet AnaesthAnalg, 2013 (in press). doi:10.1111/vaa.12129.

LUNA, S.P.L. et al. Evaluation of adverse effects of long-term oral administration of carprofen, etodolac, flunixinmeglumine, ketoprofen, and meloxicam in dogs. Am J Vet Res, v.68, n.3, p.258-264, 2007. Available from: <http://avmajournals.avma. org/doi/pdf/10.2460/ajvr.68.3.258>. Accessed: jan 14, 2014. doi: 10.2460/ajvr.68.3.258.

LYON, S.D. et al. Comparison of urine dipstick, sulfosalicylic acid, urine protein creatinine ratio, and species-specific ELISA methodologies for detection of albumin in canine and feline urine samples. J Am Vet Med Assoc, v.236, n.8, p.874-879, 2010. Available from: <http://avmajournals.avma.org/doi/pdf/10.2460/ javma.236.8.874>. Accessed: jan 14, 2014. doi: 10.2460/ javma.236.8.874.

MATSUOKA, S. Diagnostic significance of urinary enzimes in veterinary practice. Jpn J Vet Res, v.43, n.1, p.70-71, 1995.

MURISON, P.J. et al. Postoperative analgesic efficacy of meloxicam compared to tolfenamic acid in cats undergoing orthopaedic surgery. J Small Anim Pract, v.51, n.10, p.526-532, 2010. Available from: <http://onlinelibrary.wiley.com/doi/10.1111/ j.1748-5827.2010.00975.x/full>. Accessed: jan 14, 2014. doi: 10.1111/j.1748-5827.2010.00975.x.

PASCOE, P.J. et al. Effects of increasing infusion rates of dopamine, dobutamine, epinephrine, and phenylephrine in healthy anesthetized cats. Am J Vet Res, v.67, n.9, p.1491-1499, 2006. Available from: <http://avmajournals.avma.org/doi/pdf/10.2460/ ajvr.67.9.1491>. Accessed: jan 14, 2014. doi: 10.2460/ ajvr.67.9.1491.

PERKOWSKI, S.Z.; WETMORE, L.A. The science and art of analgesia. IVIS, Ithaca, 2006. Available from: <www.ivis.org>. Accessed: Ago 18, 2012.

POWER, I. et al. Effects of diclofenac on renal function and prostacylin generation after surgery. Br J Anaesth, v.69, n.5, p.451-456, 1992.

RAINSFORD, K.D. Leukotrienes in the pathogenesis of NSAID induced gastric and intestinal mucosal damage. Ag Act, v.39, p.24-26, 1993.

Ciência Rural, v.44, n.6, jun, 2014. 
RIVERS, B.J. et al. Evaluation of urine gamma-glutamyl transpeptidase-to-creatinine ratio as a diagnostic tool in an experimental model of aminoglycoside-induced acute renal failure in the dog. J Am Hosp Assoc, v.32, n.4, p.323-336, 1996.

ROSSI, G. et al. Evaluation of factors that affect analytic variability of urine protein-to-creatinine ratio determination in dogs. Am J Vet Res, v.73, n.6, p.779-788, 2012. Available from: <http://avmajournals.avma.org/doi/pdf/10.2460/ajvr.73.6.779>. Accessed: jan 14, 2014. doi: 10.2460/ajvr.73.6.779.

SLINGSBY, L.S.; WATERMAN-PEARSON, A.E. Comparison between meloxicam and carprofen for postoperative analgesia after feline ovariohysterectomy. J Small Anim Pract, v.43, n.7, p.286-289, 2002

SLINGSBY, L.S.; WATERMAN-PEARSON, A.E. Postoperative analgesia in the cat after ovariohysterectomy by use of carprofen, ketoprofen, meloxicam or tolfenamic acid. J Small Anim Pract, v.41, n.10, p.447-550, 2000
SURDYK, K.K. et al. Evaluation of glomerular filtration rate in cats with reduced renal mass and administered meloxicam and acetylsalicylic acid. Am J Vet Res, v.74, n.4 p.648-651, 2013. Available from: <http://avmajournals.avma.org/doi/pdf/10.2460/ ajvr.74.4.648>. Accessed: jan 14, 2014. doi: 10.2460/ajvr.74.4.648.

SYME, H.M. et al. Survival of cats with naturally occurring chronic renal failure is related to severity of proteinuria. J Vet Intern Med, v.20, n.3, p.528-535, 2006.

TOBIAS, K.M. et al. A comparison of four methods of analgesia in cats following ovariohys- terectomy. Vet Anaesth Analg, v.33, n.6, p.390-398, 2006. Available from: <http://onlinelibrary.wiley. com/doi/10.1111/j.1467-2995.2005.00282.x/full>. Accessed: jan 14, 2014. doi: 10.1111/j.1467-2995.2005.00282.x.

WALDROP, J.E. Urinary electrolytes, solutes, and osmolality. Vet Clin North Am Small Anim Pract, v.38, n.3, p.503-512, 2008

WRIGHT, B.D. Clinical pain management techniques for cats. Clin Tech in Small Anim Pract, v.17, n.4, p.151-157, 2002. 